\title{
Integration of Supplier and Customer's Production Processes
}

\author{
Marek Eisler $^{1}$ and Remigiusz Horbal ${ }^{2}$ \\ ${ }^{1}$ Institute of Mechanical Engineering and Automation \\ Wroclaw University of Technology \\ ul. Lukasiewicza 5 \\ 50-371 Wroclaw, Poland \\ marek.eisler@pwr.wroc.pl \\ ${ }^{2}$ Lean Enterprise Institute Poland \\ ul. Muchoborska 18 \\ 54-424 Wroclaw, Poland \\ info@lean.org.pl
}

\begin{abstract}
This paper is based on the findings from the project funded by the Ministry of Science and Higher Education of Poland. It presents the application of value stream mapping in supply chains and some inadequacy of this method for supply chain integration. Based on the findings, a new Supplier Customer Production process Integration SCPI methodology is proposed. The paper presents problems with integration of companies within the lean supply chain. Usually separate actions are undertaken by the companies within the same supply chain to implement lean management philosophy for production systems and external logistics processes. These isolated activities may lead to pushing inventories from one supply chain partner to another instead of reducing them. To reduce inventories along the supply chain the new approach of production and logistics process improvement needs to be applied. The new concept must take into consideration influence of local improvements in one plant on other cooperating enterprises as well as on the logistics system between them.
\end{abstract}

Keywords: supply chain integration, Extended Value Stream.

\section{Introduction}

Lean Manufacturing idea is well known around the world for more than two decades. Organisations in almost every country strive to use several lean tools and techniques in order to become more competitive. Many of them achieved encouraging results by improving processes and consequently competitiveness. However, authors of some publications [1], [2] claim that now and in upcoming future the competitiveness of the organisations will depend on the efficiency of the whole supply chains rather than on improved efficiency of its individual links. This means that all parties involved in a supply chain should improve theirs processes in "synchronised" way and understand that they form a system and improvement on single element of the system does not necessary result in improving the whole. This phenomenon can be observed for 
example in area of inventory management in customer and supplier plants. In some cases reduction of inventories at customer side may cause increasing inventories at supplier side [3, pp. 61-62], [4]. The inventories are pushed to suppliers rather than reduced. Therefore to reach the lowest possible level of inventories in supply chain, improvement efforts must be coordinated. Coordination of those efforts has been a popular research topic for last several years [5, pp. 12]. There are still few important issues that seem not to be resolved, such as different objectives defined by cooperating companies, excessive inventory levels or slow response to changes in customer demand [6, pp. 4-5].

The objective of the research undertaken by the authors was to propose a method to analyse and improve a selected portion of supply chains in cooperative way by customers and suppliers. Researches conducted in industry are described in section 2 of this paper. Proposed Supplier Customer Production process Integration SCPI methodology is presented in section 3. The last section 4 encompasses the conclusions.

\section{Data Collection and Analysis for a Customer-Supplier Pair}

The scope of research was limited to the pairs of cooperating companies and logistics processes between them. For data gathering and analysis researchers used Extended Value Stream Mapping method proposed by Womack and Jones in 2002 [7]. Because the supply chains are usually complex networks of organisations the research were focused on supplier - customer pairs. A pair encompasses two cooperating, manufacturing companies: a customer making products and a supplier providing components or materials for these products. Two pairs were considered in the analysis phase. Pair 1 is a part of supply chain providing home appliances. In this pair the customer company assembles finished goods and supplier company provides foamed polystyrene parts used for packaging. The second supplier - customer pair (Pair 2) belongs to the supply chain providing industrial valves. The customer company in Pair 2 is a manufacturer of industrial valves and the supplier company provides machined steel components. Conducted research encompassed a deep analysis of inventory levels in the two pairs as well as an analysis of how production processes and logistics process impacts these inventories. Summary of the most essential data is presented in Table 1.

Table 1. Summary of essential data for the analysed pairs

\begin{tabular}{|c|c|c|c|c|}
\hline $\begin{array}{c}\text { Analysed } \\
\text { pair }\end{array}$ & $\begin{array}{c}\text { Supplier's } \\
\text { finished } \\
\text { goods } \\
\text { inventory }\end{array}$ & $\begin{array}{c}\text { Transportation } \\
\text { frequency }\end{array}$ & $\begin{array}{c}\text { Transportation } \\
\text { time }\end{array}$ & $\begin{array}{c}\text { Customer's } \\
\text { component } \\
\text { inventory }\end{array}$ \\
\hline Pair 1 & 14,2 days & 3 x week & 0,1 day & 10,4 days \\
\hline Pair 2 & 8,3 days & 1 x week & 0,1 day & 9 days \\
\hline
\end{tabular}

It can be noticed that inventory levels converted to days of consumption of final customer (in both cases the final customers are retailers) are too high, especially when transportation frequency and time is considered. In case of Pair 1 components are 
delivered to the customer every 2-3 days, however the customer holds 10,4 days of inventory for those components. Also at supplier's facility in Pair 1 ready to deliver components are at high level (14,2 days). Similar situation can be noticed for Pair 2 . Even though the stock levels are lower, the level of components in customer facility seems to be too high ( 9 days) in comparison to transportation frequency (once a week = every 5 days). Such situation in both cases could be due to the fluctuations in transportation process caused by delays or incomplete deliveries as well as by changes in demand. Supplier and customer may strive to protect themselves against demand changes by increasing the level of inventories. However, the other reason of high inventories is unsynchronized production processes of supplier and customer and transportation process between them. This issue will be described in section 2.1 of this paper.

\subsection{Production and Transportation Processes Synchronization and Improvement Objectives in EVSM Method}

According to Womack and Jones "production at every stage should run on average the same rate, as adjusted for available amount of production time at each step. "[7, pp. 44] They also claim that each facility in the stream should not follow the rate of end facility. Each facility should produce each morning a leveled mix of what the next downstream facility requires for delivery in the afternoon or next morning. However, in many cases this idea is the ultimate goal company should strive to reach, but it is hardly achievable due to changeover times, breakdowns or rejects in production. Those problems force companies to produce in advance and built so called safety stocks. The authors of EVSM method propose [7, p. 45]:

- $\quad$ to reduce the noise in sending demand through the stream,

- to increase delivery frequency,

- to decreasing batch sizes,

- to level demand,

- $\quad$ or to improve capability.

This may lead to solely improving each production and logistics process in the stream as EVSM method does not give clear direction to what extent improvement at each production facility should be done. Also there are no tools proposed to identify the relations between improvements at particular supply chain link and other links.

\section{The Supplier-Customer Production Process Integration Methodology}

Due to lack of clear methodology that would allow implementing improvements in cooperating companies beneficial for the whole supply chain rather than for a solely link, authors of this article proposed the Supplier-Customer Production Process Integration (SCPI) methodology. The SCPI methodology complements EVSM method with clear guidelines for managers. The goal of the methodology is to analyse production processes of cooperating companies and transportation process between them in order to lower inventories level without harm to components availability. The 
methodology is based on EPEI index (EPEI is the acronym of Every Part Every Interval). EPEI indicates the period in which different part numbers are produced in a production process or shipped from one plant to another [8, pp.19]. The new definitions for several types of EPEI were proposed to describe flexibility of supply chain links. Introduced definitions are presented in Table 2. Fig 1 depicts referring supply chain link for each of introduced EPEI indices.

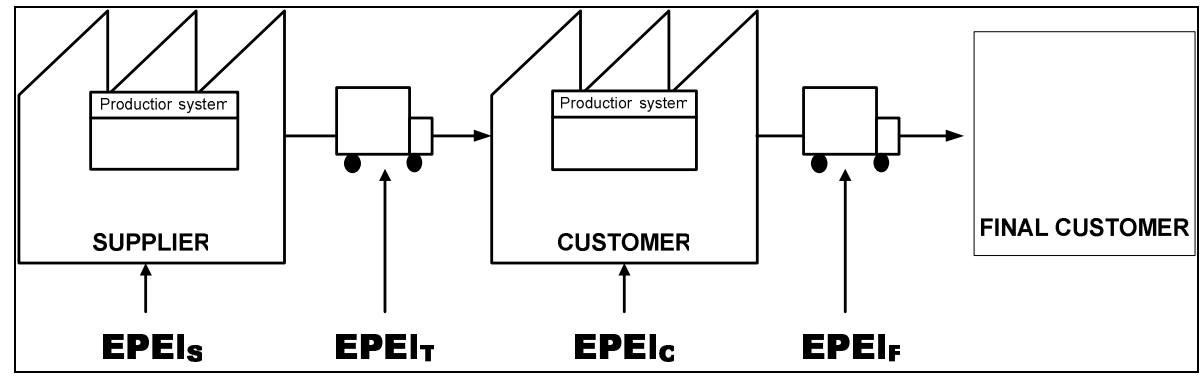

Fig. 1. Referring supply chain links for introduced definitions of different types of EPEI indices

Table 2. EPEI definitions used in SCPI methodology

\begin{tabular}{|c|c|c|}
\hline $\begin{array}{c}\text { Introduced } \\
\text { index }\end{array}$ & Definition & $\begin{array}{c}\text { Referring supply chain link } \\
\text { (see also in Fig. 1) }\end{array}$ \\
\hline $\mathrm{EPEI}_{\mathrm{F}}$ & $\begin{array}{c}\text { The period of deliveries } \\
\text { from the customer to the } \\
\text { final customer }\end{array}$ & $\begin{array}{c}\text { Final customer of supplier - } \\
\text { customer pair }\end{array}$ \\
\hline $\mathrm{EPEI}_{\mathrm{C}}$ & $\begin{array}{c}\text { EPEI index of customer's } \\
\text { production system }\end{array}$ & $\begin{array}{c}\text { Customer in supplier - customer } \\
\text { pair }\end{array}$ \\
\hline $\mathrm{EPEI}_{\mathrm{T}}$ & $\begin{array}{c}\text { The period of deliveries } \\
\text { from supplier to customer }\end{array}$ & $\begin{array}{c}\text { Transportation process between } \\
\text { supplier and customer }\end{array}$ \\
\hline $\mathrm{EPEI}_{\mathrm{S}}$ & $\begin{array}{c}\text { EPEI index of supplier's } \\
\text { production system }\end{array}$ & Supplier in supplier - customer pair \\
\hline
\end{tabular}

As mentioned above the goal of SCPI methodology is to reduce inventory levels in supply chain. Three locations of inventories in supply chain were analysed:

- components in supplier plant - finished goods from stand point of supplier that are components from customer's point of view,

- components in customer plant, that are used to assemble products (final finished goods),

- final finished goods in customer plant.

In order to allow managers of cooperating companies understand how changes in production or transportation system impacts inventory levels, authors proposed the new method of calculating required stock levels at customer and supplier company. The method combines introduced EPEI indices with a concept of standard inventory. Standard inventory encompasses three elements of inventories: cycle stock, buffer 
stock and safety stock [9]. Each element of standard inventory is defined in Table 2. Based on the proposed equations for standard inventories (see table 5) it can be noticed that standard inventories are in most cases proportional to different EPEI indices. Table 3 presents which EPEI index influence which inventories within supplier-customer pair.

Table 3. Influence of EPEI indices on standard inventory

\begin{tabular}{|c|c|c|}
\hline $\begin{array}{c}\text { Location of standard } \\
\text { inventory }\end{array}$ & \multicolumn{2}{|c|}{$\begin{array}{c}\text { EPEI index deciding about required } \\
\text { standard inventory level }\end{array}$} \\
\hline components in supplier plant & \multicolumn{2}{|c|}{ EPEI $_{\mathbf{S}}$} \\
\hline \multirow{3}{*}{$\begin{array}{c}\text { components in customer plant } \\
\text { final finished goods in customer } \\
\text { plant }\end{array}$} & $\begin{array}{c}\text { If EPEI } \\
\text { EPEI }\end{array}$ & $\begin{array}{c}\text { If } \text { If EPEI }_{\mathrm{T}}<\mathrm{EPEI}_{\mathrm{C}} \\
\mathrm{EPEI}_{\mathrm{C}} \geq\end{array}$ \\
\cline { 2 - 4 } & $\mathbf{E P E I}_{\mathbf{T}}$ & If EPEI $_{\mathrm{C}}<\mathrm{EPEI}_{\mathrm{F}}$ \\
\cline { 2 - 4 } & EPEI $_{\mathbf{C}}$ & EPEI $_{\mathbf{F}}$ \\
\hline
\end{tabular}

If assumed that neither customer nor supplier from analysed pair have influence on $\mathrm{EPEI}_{\mathrm{F}}$ index (time interval for deliveries from customer to final customer), $\mathrm{d}$ (demand of final customer) and $\mathrm{SF}_{1}, \mathrm{SF}_{2}, \mathrm{SF}_{3}$ are constant, the lowest level of final finished goods in customer plant is reached when $\mathrm{EPEI}_{\mathrm{C}}=0$. However, this is true only when $\mathrm{EPEI}_{\mathrm{C}} \geq \mathrm{EPEI}_{\mathrm{F}}$. If $\mathrm{EPEI}_{\mathrm{C}}<\mathrm{EPEI}_{\mathrm{F}}$, customer of analysed pair has bigger flexibility than final customer requires. In such situation $\mathrm{EPEI}_{\mathrm{C}}$ index has no influence on standard inventory level. Thus, the lowest standard inventory level for final finished goods hold at customer is achieved when $\mathrm{EPEI}_{\mathrm{C}}=\mathrm{EPEI}_{\mathrm{F}}$. Similarly, standard inventory levels for components at customer and for finished goods at supplier could be considered. In case of components held at customer either $\mathrm{EPEI}_{\mathrm{T}}$ or $\mathrm{EPEI}_{\mathrm{C}}$ influence standard inventory level. If $\mathrm{EPEI}_{\mathrm{T}} \geq \mathrm{EPEI}_{\mathrm{C}}$ standard inventory level will be as low as low is $\mathrm{EPEI}_{\mathrm{T}}$ index. If $\mathrm{EPEI}_{\mathrm{T}}$ is reduced till level of $\mathrm{EPEI}_{\mathrm{C}}\left(\mathrm{EPEI}_{\mathrm{T}}=\mathrm{EPEI}_{\mathrm{C}}\right)$, standard inventory level of components in customer plant will depend on $\mathrm{EPEI}_{\mathrm{C}}$. If taking into consideration reduction of $\mathrm{EPEI}_{\mathrm{C}}$ index in order to lower final finished goods standard inventory level, the lowest level of standard inventory components in customer plant will be achieved when $\mathrm{EPEI}_{\mathrm{T}}=\mathrm{EPEI}_{\mathrm{C}}=\mathrm{EPEI}_{\mathrm{F}}$. If standard inventory level for components held at supplier are considered in similar way it could be argued that inventories held in three locations (final finished goods, components and supplier's finished goods) are at the lowest level without harm to theirs availability when: $\mathbf{E P E I}_{\mathbf{S}}=\mathbf{E P E I}_{\mathbf{T}}=\mathbf{E P E I}_{\mathbf{C}}=\mathbf{E P E I}_{\mathbf{F}}$. If this is achieved, production processes of supplier and customer as well as transportation process will be synchronized. Authors of this article claim that EPEI indices related to production systems of customer and supplier as well as $\mathrm{EPEI}_{\mathrm{T}}$ could be reduced by implementation of improvements using SMED, milk run deliveries and other methods described in section 3.1. However, the cost of those improvements in many cases is not negligible. Therefore, managers of cooperating companies should strive for synchronizations in small steps. Implementing improvements in this way at each supply chain link will be better 

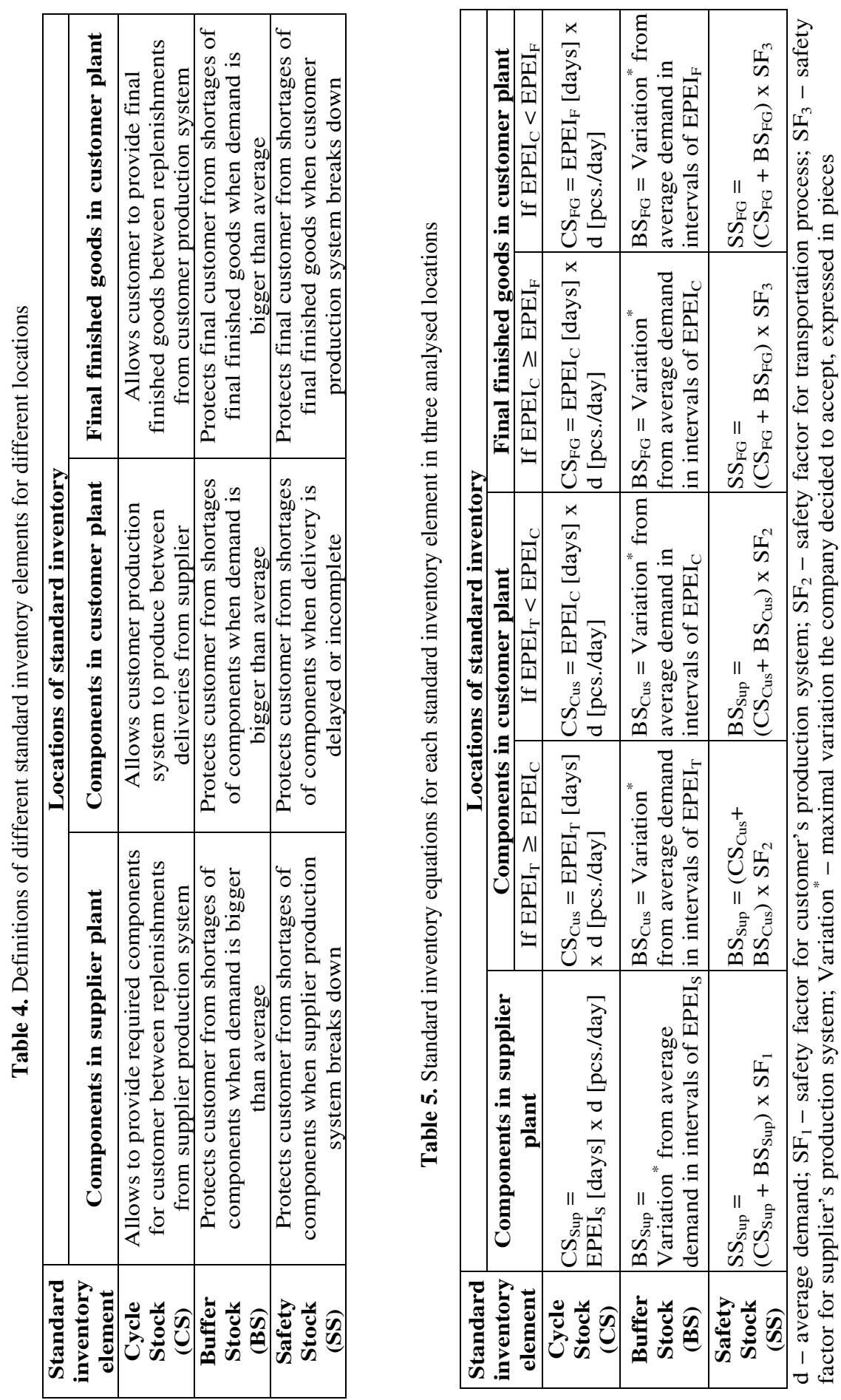
coordinated; also involved parties will be able to understand impact of local improvements on supply chain. In section 3.1 some practical solutions to lower EPEI indices are presented.

\subsection{How to Reduce EPEI Indices}

Cost of EPEI reduction in production processes as well as in transportation processes in not negligible. However there are existing and well known solutions that allows reducing EPEI indices. In area of production systems, reduction of EPEI index might be in some cases brought down to reduction of changeover times by applying SMED (Single Minute Exchange of Die) method [10]. Also decreasing number of defective products with Quality Management tools will result in EPEI indices reduction as time required for production of bad quality products increases EPEI in production system [11]. In production processes with well applied idea of continuous flow, EPEI reduction might be brought down to improvement of internal logistics process by applying kanban system and internal milk routes for frequent deliveries of components [9]. The same idea of milk runs could be also considered for reduction of $\mathrm{EPEI}_{\mathrm{T}}$ index [7], [12], [13].

\section{Conclusions}

Supply chain integration is one of the most important area for improving competitiveness of companies nowadays. Researches carried out by the authors of this article indicated that inventory levels in analysed supply chains are too high. Authors argued that this is due to lack of supplier - customer production and logistics systems' synchronization. Existing EVSM method allows mangers of cooperating companies to becom aware about too high levels of inventories but does not give clear methodology to reduce inventories in the whole supply chain. Without clear methodology for inventory reduction in supply chain, managers may implement improvements in their own companies that may cause worsening performance of other parties within the same supply chain. Therefore the SCPI methodology was proposed, which complements EVSM method with clear guidelines to follow for managers of all interested parties. The SCPI methodology is based on EPEI indices. Authors of the article argue that inventory levels are the lowest within suppliercustomer pair when all EPEI indices are equal to EPEI index of final customer that describes its flexibility $\left(\mathrm{EPEI}_{\mathrm{F}}\right)$. Proposed methodology allows managers of cooperating companies to implement improvements in theirs own companies and being aware of their impact on the whole analysed supply chain.

\section{References}

1. Goldsby, T., Martichenko, R.: Lean six sigma logistics. In: Strategic Development to Operational Success, pp. 9-10. J. Ross Publishing, Boca Raton (2005)

2. Lacioni, R.A.: New Developments in Supply Chain Management for the Millennium. Industrial Marketing Management 29, 1-6 (2000)

3. Holweg, M., Frits, K.P.: The Second Century. In: Reconnecting Customer and Value Chain through Build - to - Order. The MIT Press, Cambridge (2004) 
4. Szajter, P.: Jak zredukować zapasy materiałów przy dwukrotnym wzroście produkcji? In: 9th International Lean Manufacturing Conference, Wrocław (2009) (in Polish, not Publicized)

5. Ballou, R.H., Gilbert, S.M., Mukherjee, A.: New Managerial Challenges from Supply Chain Opportunities. Industrial Marketing Management 29, 7-18 (2000)

6. Walters, D.: Trends in the supply chain. In: Walters, D. (ed.) Global Logistics. New Directions in Supply Chain Management. MPG Books Ltd., Bodmin (2007)

7. Womack, J.P., Jones, D.T.: Seeing the Whole: Mapping the Extended Value Stream. Lean Enterprise Institute, Brookline (2002)

8. Lexicon, L.: A graphical glossary for Lean Thinkers, Version 4.0. The Lean Enterprise Institute, Cambridge (2008)

9. Harris, R., Harris, C., Wilson, E.: Making Materials Flow: A Lean Material-Handling Guide for Operations, Production-Control, and Engineering Professionals. The Lean Enterprise Institute, Brookline (2003)

10. Shingo, S.: Quick Changeover for Operators: The SMED System. Productivity Press, New York (1996)

11. Duggan, K.J.: Creating Mixed Model Value Streams. In: Practical Lean Techniques for Building to Demand. Productivity Press, New York (2002)

12. Baudin, M.: Lean Logistics. In: The Nuts and Bolts of Delivering Materials and Goods. Productivity Press, Nowy York (2004)

13. Eisler, M., Horbal, R., Koch, T.: Cooperation of Lean Enterprises - Techniques used for Lean Supply Chain. In: International IFIP TC 5, WG 5.7 Conference on Advances in Production Management Systems, Linkoping, Sweden, pp. 363-370 (2007) 